\title{
Impoliteness Strategies of Whatsapp Group Speech Community related to Local Government Policy in Handling Covid-19 Virus
}

\author{
Savitri Ayu Ida* \\ English Literature Undergraduate Study Program, Linguistics Department, Faculty of Humanities, \\ Diponegoro, University, Semarang, Indonesia
}

\begin{abstract}
When some speakers purposively use Politeness Strategy to avoid attacking hearers's by creating FTA, some other intentionally apply Impoliteness Strategy to insult hearers causing FTA. An interesting use of Impoliteness Strategy is seen in Whatsapp Group where speakers feels free to speak up in private and limited areas inside the Whatsapp Group. This research discuss how some speakers deliberately use Politeness Strategy in commenting local government policies related to Covid-19 safety protocol.
\end{abstract}

\section{Research Bakcground}

In a certain speech community of a particular speech society such as an on line speech community of a Whatsapp Group, speakers or members of the Whatsapp Group generaly feel free to speak up as they realize that the whole Whatsapp Group members belong to the same background and having the same shared knowledge so that they become intimate each other resulted in freedom of expressing what they feel.

One of the signs reflecting the freedom of speech is the way speakers or members of the Whatsapp Group purposively give negative comment to attack others' post creating FTA for the speakers who were being insulted. The negative comments containing Impoliteness Strategy may insult the person being attacked by the comment since it plays as sarcasm or irony and may also create humor since it plays as joke.

This research discuss how members of Whatsapp Group use Impoliteness Strategy in giving comment on local government policy related to Covid-19 safety protocol to purposively insult the person posting his/her statement or the person in his/her post. It can also done to create bitter smile of his/her satire. The Theory, Strategy and Type are used to analyse impolite message by identifying the impolitenes, categorizing the strategy and the type, and describing the purpose of being impolite to show how a speech community (whatsapp group) in a speech environment (alumni of Tegal Elementary, Junior and Highschool) show their impoliteness.

The result shows how speakers intentionally not giving polite written comment of particular topics using impoliteness strategies to attack hearers or their post by holding

* Corresponding author: aidaarsjaad@gmail.com 
Face Threatening Act. It becomes one of language choices they take which indirectly shows how a particular speech community shows impolitenes in their speech

\section{Theoretical Background}

To run a good communication without bearing any misunderstanding leading into verbalor psysical conflict, a speaker should follow communication guidances such as Grice's Cooperative Principle[1] or Brown and Levinson' Politeness Principle[2]. The first pinciple guides speaker to hold a good communication by sending a correct, adequate, relevant and unambiguous message to hearer. Meanwhile, the second principle guides speaker to respect hearer by sending polite message to avoid attacking hearer by creating Face Threatening Act.

At this point, both principles can violate each other. When a speaker is requested to say true, necessary, relevant and unambiguous message by obeying the four maxims of Quality, Quantity, Relation, and Manner; he or she can send impolite message that make hearer upset or insulted by violating the four Politeness Strategy of Bald on Record Politeness, Positive Politeness, Negative Politeness, Off Record Politenes and Don't Do the FTA as he or she is saying something as it is without considering hearer's want to be respected, burdening hearer with unnecessary message, quipping hearer or doing Face Threatening Act.

Grice's Cooperative Principles was then being extracted by Sperber dan Wilson to formulate Relevance Theory[3] where ideal communication rely on the language coding formulation, language coding transfer, and language coding reading along with important elements such us inference andlanguage context so that only relevant message is going to be processed in a good communication. In this way, as long as a message is considered relevant by hearer, the communication will be running without considering Cooperative and Politeness Principles.

Unlike those three communication principles above, Impoliteness Principle[4] -drawn from Brown-Levinson's Politeness Principle[2] - discusses a unique phenomenon where speaker puposively use Impoliteness Strategy specifically designed to attact hearer's face (creating Face Attack Act) resulting ini social conflict and disharmony[5].

Culpeper considered Impoliteness Theory as the parasite of Brown-Levinson's Politeness Principle[2] by formulating 5 (five) Super Strategies of Bald on Record Impoliteness in which speaker deliberately and obviously do Face Attack Act, Positive Impoliteness in which speaker damage hearer's positive face by neglecting hearer's want to be accepted, Negative Impoliteness in which speaker damage hearer's positive face by burdening hearer with speaker's message, Sarcasm or Mock Impoliteness in which speaker do the Face Attack Act by showing obvious unsincere Politeness Strategy, and Withhold Impoliteness in which speaker purposively choose not to be polite (being impolite) to hearer where he or she should be polite to hearer.

Culpeper[6] divides type of Impoliteness into Affective Impoliteness in which speaker shows anger to hearer creating negative athmosphere, Coercive Impoliteness in which speaker take granted from hearer (under circumstance where hearer's social status is lower than speaker), and Entertaining Impoliteness in which speaker poke fun on hearer and make hearer's low feeling of being poked as something fun for speaker.

\section{Methodology}

To hold the research properly, the researcher divides the data collection process into two major steps. A digital data collection is done by observing 3 (three) whatsapp group of 
the alumni of Elementary, Junior and Senior Highschool in Tegal by taking 5 (five) research objects in the form of the impolite comment containing five super strategies using Purposive Sampling Technique[7] to explain its strategy and to categorize its type.

Then, 3 (three) research subjects in the form of 1 (one) alumni of elementary school, 1 (one) alumni of junior highschool, and 1 (one) alumni of senior highschool were taken using Random Sampling Technique[7] using Documentation and Interview techniques by applying Participatory Method[8] to understand why those three subjects were purposively being impolite. The researchers also dig more information from the informant by giving Questionnaire to see their culture and language background to support the final conclusion of this research.

After the whole data were obtained, the researchers analyse it in two major steps: (1) categorizing the strategy and (2) categorizing the type. In the meantime, the information obtained from the informants is analyse to know whether (1) the informants purposively being impolite or not, (2) how they show their impoliteness, and (3) why they were being impolite.

\section{Finding and Discussion}

\subsection{Finding}

For the research finding, the researcher found 15 (fifteen) Impoliteness Super Strategies in the comments of the research subjects as follows.

Table 1. Research Finding

\begin{tabular}{|c|c|c|c|}
\hline $\begin{array}{c}\text { Five } \\
\text { Impoliteness } \\
\text { Super Strategies }\end{array}$ & $\begin{array}{c}\text { Elementary School } \\
\text { (A) }\end{array}$ & $\begin{array}{c}\text { Junior Highshool } \\
\text { (B) }\end{array}$ & $\begin{array}{c}\text { Senior Highschool } \\
\text { (C) }\end{array}$ \\
\hline $\begin{array}{l}\text { Bald on Record } \\
\text { Impoliteness (1) }\end{array}$ & $\begin{array}{l}\text { Koen geleman sich ndah } \\
\text { wong koen ws mampu ya }\end{array}$ & $\begin{array}{c}\text { Sing reang } \\
\text { tak lockdown } \\
\text { (the mayor meme) } \\
\end{array}$ & $\begin{array}{c}\text { Jaluk menange dewek } \\
\text { JARKONI } \\
\text { (the president meme) }\end{array}$ \\
\hline $\begin{array}{c}\text { Positive } \\
\text { Impoliteness (2) }\end{array}$ & $\begin{array}{c}\text { Tp ngarep umahe } \\
\text { distempel keluarga miskin } \\
\text { gelem ndah }\end{array}$ & $\begin{array}{c}\text { Trafo jln Sultan agung } \\
\text { njeblug }\end{array}$ & $\begin{array}{c}\text { Kl ada yg mati } \\
\text { ya ga hebatlah meskipun } \\
\mathrm{cm} 1\end{array}$ \\
\hline $\begin{array}{c}\text { Negative } \\
\text { Impoliteness (3) }\end{array}$ & $\begin{array}{l}\text { Boleh mudik asal } \\
\quad \text { jalan kaki }\end{array}$ & $\begin{array}{c}\text { Ho'oh. } 14 \text { hari diisolasi } \\
\text { mandiri. Ojo cedak2 } \\
\text { termos liyane. }\end{array}$ & $\begin{array}{c}\text { Kata2 mudah ditulis dan } \\
\text { diucapkan tapi... } \\
\text { (wise people emoticon) }\end{array}$ \\
\hline $\begin{array}{l}\text { Sarcasm / Mock } \\
\text { Impoliteness (4) }\end{array}$ & $\begin{array}{c}\text { Kuwe sing jenenge } \\
\text { perintah cerdas } \\
\text { sing di penjara napi2 } \\
\text { komplotan pembunuh } \\
\text { begal pemerkosa bakul } \\
\text { narkoba } \\
\text { di bebaskan giliran wong } \\
\text { arep mudik pengen ketemu } \\
\text { kro anak bojo niate apik2 } \\
\text { malah di penjara } \\
\text { di denda } 100 \text { juta duite } \\
\text { mardiah }\end{array}$ & $\begin{array}{c}\text { Customer } 2 \text { JKT emang } \\
\text { pada kaya *su ka SIM } \\
\text { hobby komplain padahal } \\
\text { Nang kantor kerjane } \\
\text { paling kacung dadi keset } \\
\text { tok,salah ora salah di } \\
\text { ganyami Bose mangkane } \\
\text { wanine Maring ojol } \\
\text { tok...kepret nganggo *eli }\end{array}$ & $\begin{array}{c}\text { Beda memang yen bekinge } \\
\text { Kapolda Metro (smiling } \\
\text { by } \\
\text { covering mouth } \\
\text { with hands emoticon) }\end{array}$ \\
\hline $\begin{array}{c}\text { Withold } \\
\text { Impoliteness (5) }\end{array}$ & $\begin{array}{l}\text { Apa Bae ws ndah sing } \\
\text { penting kena go crita }\end{array}$ & $\begin{array}{c}\text { Udu terpapar maning } \\
\text { tapi terkapar } \\
\text { gara } 2 \text { psbb ... } \\
\text { (crying emoticon) }\end{array}$ & $\begin{array}{c}\text { Imin ga diperhatiin ya } \\
\text { kasihan }\end{array}$ \\
\hline
\end{tabular}




\subsection{Discussion}

From Table 1, we see that the research subjects produce Bald on Record Impoliteness by deliberately and obviously do Face Attack Act to hearer such as: (1) the elementary school speaker said, "Koen geleman sih, Ndah. Wong koen wis mampu ya?" meaning "You want the money although you are not poor?" commenting the hearer request to get the local government's help (money) although she is not poor; (2) the junior highschool speaker said, "Sing reang tak lockdown," commenting the hearer's complaint about the local lockdown applied by the local government; and (3) the senior highschool speaker said, "Njaluk menange dewek. Jarkoni." commenting the hearer's statement about the government who give bad example of social-physical distancing (their press conference made a lot of journalists flocked to the site neglecting the Covid-19 protocol).

We also see that the research subjects produce Positive Impoliteness in which speaker damage hearer's positive face by neglecting hearer's want to be accepted such as: (1) the elementary school speaker said, "Tapi ngarep umahe ditempel keluarga miskin gelem, Ndah?" meaning "But, (is it okay) if your house got poor family sticker?" commenting the hearer's request to get the local government's help (money) as the hearer wants to be accepted as part of the whole citizen who were listed to get the help, not as the poor family; (2) the junior highschool speaker said, "Trafo Jalan Sultan Agung njeblug." commenting the hearer's statement about the local government's policy to turn off most of main streets' lamps at night to minimize people to go oustide the house) by saying, "Kiye giliran PLN di-lockdown ya?" meaning, "Is it the time for PLN to be locked down?" as the hearer wants the speaker to know that the dark night is part of the local government's policy but it turned out that it is happening because of an accident, not a lock down; and (3) the senior highschool speaker said, "Kalo ada yang mati ya nggak hebatlah meskipun cuma satu." meaning, "It is not great if there is still victim, even only one." commenting the hearer's statement saying that Singapore is great to have only twenty two death cases when they got thirty thousands positive cases.

Related to Negative Politeness in which speaker damage hearer's positive face by burdening hearer with speaker's message, we can see that the research subjects produce: (1) the elementary school speaker said, "Boleh mudik asal jalan kaki." meaning "You are allowed to go home as long as you walk." commenting the hearer's complaint about the local government ban to go home to show how hard it is for the hearer to go home; (2) the junior highschool speaker said, "Ho'oh. 14 hari diisolasi mandiri. Ojo cedak-cedak termos liyane." answering the hearer's question whether the local government's policy of fourteen days self quaranteen also applied to stuff like water jug to let the hearer see how difficult it is to keep ourselves free from the virus; and (3) the senior highschool speaker said, "Kata-kata mudah ditulis dan diucapkan tapi..." meaning "Words are easier to say than to do." commenting the hearer's comment of "Jarkoni" or "bisa ujar ora isa nglakoni" meaning "Easier to say than to do" to let the hearer understand that it is not easy to do as the local government also do the same by holding press conference and ceremony related to the local lockdown or PSBB.

The most impolite strategy, Sarcasm or Mock Impoliteness in which speaker do the Face Attack Act by showing obvious unsincere Politeness Strategy, is produced by the research subjects when: (1) the elementary school speaker post, "Kuwe sing jenenge perintah cerdas. Sing di penjara, napi-napi, komplotan pembunuh, begal, pemerkosa, bakul narkoba, dibebaskan. Giliran wong arep mudik, pengen ketemu karo anak bojo, niate apik-apik malah dipenjara, didenda 100 juta. Duite Mardiah." meaning, "That is smart policy. Those imprisoned prisoners, killers, robbers, rapers, drug dealers, were freed. But people who want to go home to see their wife and childred under their good will were imprisoned (and) got fined 100 million. (Should we pay with) Mardiah's money? 
(local people legend owing lots of money)." mocking the hearer's post about 100 million fine and being imprisoned sanction for those who want to go home for Lebaran (Islamic holy day); (2) the junior highschool speaker said, "Customer-customer Jakarta emang pada kaya *su ka, Sim. Hobby komplain padahal nang kantor kerjane paling kacung. Dadi keset tok. Salah ora salah diganyami bose. Mangkane wanine maring ojol tok. Kepret nganggo *eli." meaning, "Jakarta's customers are bad as they like to complaint since they only work as lower employees being complaint by their bosses eventhough they make no mistake, but they cannot complaint back; so they complaint to on-line motorcycle service." commenting the hearer's moan of being complained by a customer as he forgot to wear face masker when he delivered the customer's order; and (3) the senior highschool speaker said, "Beda memang yen bekinge Kapolda Metro." meaning, "It makes difference when you got someone big as your back up." commenting the hearer's statement boasting that he can go home easily unlike everybody else.

The last impoliteness strategy, Withhold Impoliteness in which speaker purposively choose not to be polite to hearer where he or she should be polite to hearer, is shown by the research subjects when: (1) the elementary school speaker said, "Apa bae wis, Ndah. Sing penting kena go crita." meaning "Anything you wish." to show that the speaker pretends to give anything the hearer want but actually he gives up dealing with what the hearer's want; (2) the junior highschool speaker said, "Udu terpapar maning, tapi terkapar gara-gara PSBB." meaning, "Not only got exposed but also being dropped dead because of PSBB." showing that the speaker pretends to gave up everything eventhough he can survive; and (3) the senior highschool speaker said, "Imin nggak diperhatiin ya? Kasihan," commenting the hearer's statement about the new normal phenomenon where iman (belief) and imun (imunity) are important indealing with Covid-19 to show that the speaker pretends to pay attention on imin while he is only joking.

\section{Conclusion}

Nine of the fifteen impoliteness strategies belong to Affective Impoliteness where speaker shows dislike to hearer leading to negative feeling. Four of it belongs to Coercive Impoliteness where speaker take granted from hearer whose social status is lower than speaker like B1, B2, B4 and C2. Two of it belongs to Entertaining Impoliteness where speaker poke fun on hearer and make it as something fun like C4 and C5. It can be said that the speaker obviously hold the impoliteness leading to negative athmosphere in their speech community as they have intimate relationship among all participants so that the negative feeling can be forgiven and forgotten.

\section{References}

[1] Grice, H.P. "Logic and Conversation" in Cole, P. and Morgan, J. (ed.). Syntax and Semantics: Speech Acts. New York: Academic Press. (1975)

[2] Brown, P. and Levinson, S. Politeness: Some Universals in Language. Cambridge: Cambridge University Press. (1987)

[3] Sperber, D. and Wilson, D. A. Relevance. Communication and Cognition. Cambridge: Cambridge University Press. (1986)

[4] Culpeper, J. and Kàdàr, D. Historical (Im)politeness. Bern: Peter Lang. (2010)

[5] Bousfield, D. and Locher, M. (eds.). Impoliteness in Language: Studies on Its Interplat with Power in Theory and Practice. Berlin: Mouton de Gruyter. (2008)

[6] Culpeper, J. Impoliteness: Using Language to Cause Offence. Cambridge: Cambridge University Press. (2011)

[7] Sugiyono. Metode Penelitian Kualitatif dan R\&D. Bandung: CV Alfabeta (2010) 
[8] Sudaryanto. Metode dan Aneka Teknik Analisis Bahasa. (Pengantar Penelitian Wacana Kebudayaan secara Linguistik). Yogyakarta: Duta Wacana (1993)

[9] Mohammed, H.N. and Abbas, N.A. Pragmatics of Impoliteness and Rudeness. American International Journal of Social Science Vol. 4, No. 6, December 2015, Pp.195. College of Education for Women, Baghdad University. 